\title{
AN ANALYSIS ON STUDENTS' ERRORS IN PRONOUNCING ENGLISH WORDS
}

\author{
Andi Idayani \\ Islamic University of Riau \\ Email:andiidayani@edu.uir.ac.id
}

\begin{abstract}
The objective of this research is to know the students' errors in pronouncing of English words on vowel and consonant sounds in the first semester of English students of FKIP UIR. The research design of this study is descriptive research. The researcher assessed the students' errors pronunciation at English Language Education of FKIP UIR. The Respondent of this research was the first semester of English students of FKIP UIR. In this study, the research instrument is an oral test, there are 40 words that be tested, and the data was collected by a recorder. In analyzing the data, the researcher helped by other English lecturers as raters. Then, the data was checked by using talking-talking software and phonetic transcription. The result of this study described that there are some errors made by students in pronouncing English words. There are 25 students' errors pronounced short vowel /e/, 15 students' errors pronouncing short vowel/U/, 21 Students' errors pronouncing the consonant / $\mathrm{d} /, 18$ students' errors pronouncing consonant $/ \Theta /$, and 17 students' errors pronouncing consonant $/ 3 /$.
\end{abstract}

Keywords: An Analysis, Students' errors, Pronunciation.

\begin{abstract}
Tujuan dari penelitian ini adalah untuk mengetahui kesalahan mahasiswa dalam mengucapkan kata - kata bahasa Inggris pada bunyi vokal dan konsonan pada semester pertama mahasiswa bahasa Inggris di FKIP UIR. Desain dalam penelitian ini adalah penelitian deskriptif. Peneliti menilai kesalahan pengucapan mahasiswa di Pendidikan Bahasa Inggris FKIP UIR. Responden dari penelitian ini adalah mahasiswa semester pertama Pendidikan Bahasa Inggris FKIP UIR. Dalam penelitian ini, instrument penelitian adalah tes lisan, ada 40 kata yang diuji, dan data dikumpulkan dengan malakukan perekam hasil pengucapan mahasiswa satu persatu secara bergantian. Dalam menganalisis data, peneliti dibantu oleh dosen bahasa Inggris lainnya sebagai penilai. Kemudian, data diperiksa dengan menggunakan talking - talking software dan transkripsi fonetik. Hasil penelitian ini menggambarkan bahwa ada beberapa kesalahan yang dilakukan oleh mahasiswa dalam mengucapkan kata-kata bahasa Inggris. Ada 25 kesalahan siswa pada pelafalan bunyi vokal pendek /e/, 15 kesalahan mahasiswa pada pelafalan huruf vokal pendek /u/, 21 kesalahan mahasiswa pada pelafalan bunyi konsonan /ð/, 18 kesalahan siswa pada pelafalan huruf konsonan /ø/, dan 17 kesalahan siswa mengucapkan konsonan /3/.
\end{abstract}

Kata kunci: Analisis, Kesalahan Mahasiswa, Pengucapan 


\section{INTRODUCTION}

Nowadays, everybody learns the English language to communicate with others. The students who use the English language in communication should speak English correctly and fluently. Therefore, when students uttering the idea or talk about something in communication, they ensure that the audience understands what they have uttered.

Sounds are very important in language. Its produce the phonemes to understand spoken sentences. Moreover, sounds are the vibration that travels through the air that can be heard when they reach a person's ear. Furthermore, the sounds are transmitted from the speaker to the hearer, and acoustic and auditory phonetic focus on the speech physics and the form of the sound wave through the air, where the waves have on hearer's ears and brain. Moreover, in learning English, the students should know the system of English sound. Then, they have to know how to pronounce every single English speech sound. All around the world, there are a lot of people still get difficulties in producing sounds and still hard to pronounce some English words. Furthermore, they lack practice in pronouncing English words.

Following that, correct pronunciation will give clear idea or meaning in communication to avoid misinterpretation so that students have to learn how the words are pronounced. There are several difficulties that faced by students in learning process pronunciation such as the system differences between the native and the foreign language, the influence of spelling on the pronunciation, and the inconsistency of pronouncing some English letter affects in pronunciation.

In other words, the learners who learn the English language as a second language or as a foreign language meet some difficulties and making errors, because the first language affects his second language especially in adulthood and this effect is a result of first language transfer. It is a significant source of making errors for second language (Brown, 2000). An error is something happen when the students 
unsuccessful in determining a new language or second language. The students have a lack of knowledge of it because they do not realize what they did is an error unless other people explain about it. They cannot correct that error by themselves.

Furthermore, according to Dulay, Burt and Krashen(1982) state that there are classify error into four types; error based in the linguistic category (phonology, syntax, morphology, semantics, lexicon, and discourse). Furthermore, the students of English language education of FKIP UIR have learned pronunciation subject in the first semester in their college. However, the students and the lecturer use the English language in the learning process. In fact, the Student's activities in the classroom always use the English language in communication to improve their understanding of English. Although the students have learned about English, the students still found a problem such as the way to pronounce English words. The English students of FKIP UIR still make errors in pronouncing some
English words; especially in pronouncing the words that unfamiliar with them.

In this study, the researcher simplifies on 5 long vowels sounds: /i:/,/a:/,/u:/,/s:/,/3:/. 6 short vowels sounds: $/ \mathrm{I} /, / \mathrm{e} /, / \mathfrak{x} /, / \Lambda /, / \mathrm{\partial} /, \mathrm{U} /$, and 6 consonants sounds: $/ \mathrm{J} /, / \mathrm{g} /, / \Theta /, / \circlearrowright /$, $/ 3 /, / d z /$. The general objective of the research is the researcher wants to know the Student's errors in pronunciation of English words on vowel and consonant sounds at English students of FKIP UIR.

Language learners may find difficulties in learning to speak English well because much spelling may be represented by a single sound. Moreover, for the learner, it can be a hard thing and difficult process to learn about the sound of speech. Because in English there so many symbols that the learner should know to pronounce correctly.

Although it needs time to learn the sound of speech, it is necessary for the learner to learn the English language as a second language. Moreover, good pronunciation makes people easy to understood in communication in the 
English language and easy for the learner to express their expression. For the learner to mastery in pronunciation is a necessary and important thing in learning the English language.

\subsection{Vowels Sounds}

A vowel is speech sound in which the mouth is open and the tongue is not touching the top of the mouth and the teeth. According to Connor (1980) said that vowels are made by voiced air passing through different mouth shapes; the differences in the shape of the mouth are caused by the different position of the tongue and lips.

Vowels can be either front or back. In front of a vowel, such as as/i/ or $/ æ /$, the front part of the tongue is pushed forward, and the tongue can be easily seen in a mirror. In the back vowel such as $/ \mathrm{u} /$ or $/ \mathrm{a} /$, the highest point of the tongue is back and the whole tongue moves back in the mouth.

\subsection{Consonant Sounds}

A consonant is speech sound made by stopping breathing with the tongue and lips. Consonants are the speech sounds which are produced with someone kind of closure in the mouth by restricting the escape of air. In addition, consonants are sounds that interrupt or restrict the flow of air.

In learning the English language, the students not only know how to pronounce the vowels sounds but also how to pronounce the consonants sounds correct in the English word.

According to Indriani (2003) states that there are twenty-four of consonants which number are classified based on place of articulation and manner of articulation.

\section{METHOD}

The researcher used descriptive research to carry out this study. In this study, the researcher analyzed students' errors in pronouncing the words on vowels and consonants sounds throughout data recording. The population of this research was the first semester of English students of FKIP UIR. The total of this population was 159 students. Thus, the researcher was 
took $2 \mathrm{~A}$ class as the respondent in this study.

\subsection{Research Instrument}

In this study, the research instrument is an oral test. In this test, the respondents have pronounced the English word loudly. The test consists of 40 words. Among of them are five long vowels sounds (/i:/,/a:/,/u:/,/っ:/,/3:/), six short vowels sound $(/ \mathrm{I} /, / \mathrm{e} /, / \mathfrak{m} /, / \Lambda /, / \mathrm{/} /, / \widetilde{J} /)$, and six consonants sounds: $/ \mathrm{J} /, / \mathrm{t} /, / \Theta /, / \mathrm{d} /$, /3/, /dz/. The researcher has given students a paper that the words which going to be tested, the researcher took the words from a book and dictionary. The selected words are familiar words that pronounce unfamiliar sounds of each the word. The researcher chose those words because almost students often hear the words but sometimes the students are incorrect in pronouncing.

\subsection{Data Collecting Technique}

In this research, since the instrument is an oral test, it used to measure Student's abilities in pronouncing some words and to know how many students make errors in pronouncing.
The researcher was used as a recorder as a piece of equipment to record the Student's voice. Then, the students were asked to read aloud.

There are some procedures for taking the data as follow:

1. The researcher gave instruction to the students.

2. The researcher called the students one by one.

3. The researcher asked the students to mention their names first in the record begin.

4. The researcher recorded the Student's pronouncing those words one by one.

5. The researcher gave several minutes for each student to pronounce those words.

6. The researcher analyzed the Student's pronunciation by hearing the recorder.

\subsection{Data Analyzing Technique}

There are some ways or steps to analyze the data. The steps as follow:

1. The record was checked it by using talking-talking software and through lookup phonetic 
transcription in order to found the correct and incorrect pronounced.

2. Checked out the data of students especially how many words that were pronounced correctly by the English students.

\section{FINDINGS AND DISCUSSION}

This chapter presents the research findings with the data analyzed and interpreted, which have been taken from the respondents' to An Analysis Student's Errors in Pronunciation at English Language Education of FKIP UIR.

Furthermore, the main objective of this research is to find out what kinds of errors done by students of English Language Education of FKIP UIR in pronouncing English words.
There are 40 words that were tested in this research, they are 10 words of long vowel sound, and there are 5 long vowel sounds, each sound multiplied by two words. Moreover, there are 14 words of the short vowel that were tested, and there 7 of long vowel sound, each sound multiplied by two words. Furthermore, there are 5 words of affricative sound, and there are 2 affricative consonant sounds, but for the sound of $/ \mathrm{t} /$ multiplied by three words in this research. The last, there are 16 words of fricative sound, and there are 4 sounds of fricative sounds, for fricative consonants sounds / $/ 3 /$ only 2 words, and for the fricative consonant sound $/ \mathrm{J} /, / 3 /, / \mathrm{d} /$ multiplied by three words.

Table 1.Calculation of Student's Errors

\begin{tabular}{|c|c|c|c|c|c|c|}
\hline No. & Students & $\begin{array}{c}\text { Long } \\
\text { vowels }\end{array}$ & $\begin{array}{c}\text { Short } \\
\text { Vowels }\end{array}$ & Affricative & Fricative & $\begin{array}{c}\text { Total } \\
\text { Errors }\end{array}$ \\
\hline 1 & Students 1 & 4 & 4 & 2 & 5 & 15 \\
\hline 2 & Students 2 & 4 & 4 & 2 & 9 & 19 \\
\hline 3 & Students 3 & 1 & 3 & 2 & 3 & 9 \\
\hline 4 & Students 4 & 3 & 1 & 2 & 4 & 10 \\
\hline 5 & Students 5 & 1 & - & 1 & 1 & 3 \\
\hline 6 & Students 6 & 2 & 2 & 1 & 5 & 10 \\
\hline 7 & Students 7 & 1 & 2 & - & 4 & 7 \\
\hline
\end{tabular}




\begin{tabular}{|c|c|c|c|c|c|c|}
\hline 8 & Students 8 & 1 & 3 & 2 & 3 & 8 \\
\hline 9 & Students 9 & 1 & 4 & 1 & 3 & 9 \\
\hline 10 & Students 10 & - & 5 & 2 & 6 & 13 \\
\hline 11 & Students 11 & 2 & 3 & 3 & 5 & 13 \\
\hline 12 & Students 12 & 1 & 4 & - & 3 & 8 \\
\hline 13 & Students 13 & - & 3 & 1 & 4 & 8 \\
\hline 14 & Students 14 & 1 & 2 & 1 & 5 & 9 \\
\hline 15 & Students 15 & 2 & 2 & 2 & 6 & 12 \\
\hline 16 & Students 16 & - & 2 & 3 & 4 & 9 \\
\hline 17 & Students 17 & 2 & 4 & 4 & 7 & 17 \\
\hline 18 & Students 18 & 2 & 4 & 2 & 4 & 12 \\
\hline 19 & Students 19 & - & 3 & - & 5 & 8 \\
\hline 20 & Students 20 & 1 & 2 & 3 & 5 & 11 \\
\hline 21 & Students 21 & - & 1 & - & 4 & 5 \\
\hline 22 & Students 22 & 2 & 2 & 4 & 7 & 15 \\
\hline 23 & Students 23 & - & 3 & 1 & 3 & 7 \\
\hline 24 & Students 24 & - & 3 & 1 & 4 & 8 \\
\hline 25 & Students 25 & 1 & 2 & 1 & 4 & 8 \\
\hline 26 & Students 26 & - & 3 & - & 3 & 6 \\
\hline 27 & Students 27 & - & 3 & 1 & 3 & 7 \\
\hline 28 & Students 28 & 1 & 4 & 4 & 10 & 19 \\
\hline & Total & 33 & 78 & 46 & 42 & 226 \\
\hline
\end{tabular}

Based on the table, it can be

Then, errors on short vowel sound is seen that the Student's errors pronouncing English words in English language education of FKIP UIR. There are 226 errors made by Students in pronouncing English words. The Students' errors on long vowels were 17, the Students' errors on short vowel were 52, errors on fricative sound were 115, and the last Students' errors on affricative sound were 42.

$(13,26 \%)$. The last is errors on Long vowels $(6,07 \%)$.

Based on the explanation, it can be concluded that the difficulties in the learning process of pronunciation not only caused by lack of knowledge and practice, but also student's attitude toward English subject especially the habit of students in the learning process of English pronunciation.

Moreover, the frequent percentages of errors are fricative sound (30\%). After that followed by errors on affricative sound $(25,66 \%)$. 


\section{CONCLUSION}

Pronunciation in English is important for learners, language learners should pay more attention the way they articulate the foreign words, so they are sure that they can communicate what they have in mind. They have to understand when they are uttering the words. Pronunciation is using to support the successfulness message from the speaker to the listener to avoid misunderstanding. On the other hand, appropriate English pronunciation will make people easier to understand in communication. In addition, in mastering pronunciation, they will know how to pronounce each English word correctly and clearly.

Moreover, the students of English language education of FKIP UIR have learned pronunciation subject in the first semester in their college. Although the students have learned about English, the students still found a problem such as the way to pronounce English words. The English students of FKIP UIR still make errors in pronouncing some
English words, especially in pronouncing the words that unfamiliar with them.

Additionally, the writer got a conclusion after analyzed all word of the test. The writer sees, mother tongue factor was a big influence in English pronunciation and lack of practice. Although the researcher was presented the familiar words in the test, the students still made errors in pronouncing the English words.

Based on the result of this study, the researcher suggested that the students do more practice in English pronunciation so that they will be correct to pronounce the words.

\section{REFERENCES}

Arikunto, Suharsini. (2013). Prosedur penelitian: suatu pendekatan praktik. Jakarta: Rineka Cipta.

Brown, H.D. (2000). Principles of Language Learning and Teaching ( $4^{\text {th }} e d$.). Longman: San Francisco State University. 
Burns, A. (2003). Clearly Speaking: Pronunciation in Action For Teachers. National Centre for English Language Teaching and Research. Sydney: Macquarie University.

Creswell, Jhon W. (2014). Research Design. Qualitative, Quantitative, and Mixed Method Research. Washington DC: SAGE Publication.

Dalton, Christiane, and Seidhofer, Barbara. (1994). Language Teaching Pronunciation. New York: Oxford University Press.

Katamba, Francis. (1989). An Introduction to Phonology. New York: London.

Hayes, Bruce. (2009). Introductory Phonology. Singapore: Markono Print Media.

Indriani, M.I. (2003). English Pronunciation: The English Speech Sounds Theory and Practice. Jakarta: PT Gramedia Pustaka Umum.

Kenworthy, Joanned. (1987). Teaching English Pronunciation. London: Longman

O'Connor, J.D.(1980). Better English Pronunciation $\left(2^{\text {nd }}\right.$ ed). Cambridge: Cambridge University Press.
Wilkins, D.A. (1980). Linguistics In Language Teaching. Great Britain: Chaucer Press. 